\title{
Comparison of two methods of tear sampling for protein quantification by Bradford method ${ }^{1}$
}

\author{
Eliana Farias ${ }^{2}$, Katia L. Yasunaga $\dagger^{2}$, Romulo V.R. Peixoto ${ }^{2}$, Micaella P. Fonseca ${ }^{3}$, \\ Wagner Fontes ${ }^{3}$ and Paula D. Galera ${ }^{2 *}$
}

\begin{abstract}
Fraias E., Yasunaga K.L., Peixoto R.V.R., Fonseca M.P., Fontes W. \& Galera P.D. 2013. Comparison of two methods of tear sampling for protein quantification by Bradford method. Pesquisa Veterinária Brasileira 33(2):261-264. Faculdade de Agronomia e Medicina Veterinária, Universidade de Brasília, Campus Dracy Ribeiro, Asa Norte, ICC Sul, Brasília, DF 70910-970, Brazil. E-mail: paulaeye@unb.br

The aim of this study was to compare two methods of tear sampling for protein quantification. Tear samples were collected from 29 healthy dogs (58 eyes) using Schirmer tear test (STT) strip and microcapillary tubes. The samples were frozen at $-80^{\circ} \mathrm{C}$ and analyzed by the Bradford method. Results were analyzed by Student's t test. The average protein concentration and standard deviation from tears collected with microcapillary tube were $4.45 \mathrm{mg} / \mathrm{mL} \pm 0.35$ and $4,52 \mathrm{mg} / \mathrm{mL} \pm 0.29$ for right and left eyes respectively. The average protein concentration and standard deviation from tears collected with Schirmer Tear Test (STT) strip were and $54.5 \mathrm{mg} / \mathrm{mL} \pm 0.63$ and $54.15 \mathrm{mg} / \mathrm{mL} \pm 0.65$ to right and left eyes respectively. Statistically significant differences $(p<0.001)$ were found between the methods. In the conditions in which this study was conducted, the average protein concentration obtained with the Bradford test from tear samples obtained by Schirmer Tear Test (STT) strip showed values higher than those obtained with microcapillary tube. It is important that concentration of tear protein pattern values should be analyzed according the method used to collect tear samples.
\end{abstract}

INDEX TERMS: Tear sampling, protein, Schirmer, microcapillary, Bradford method.

RESUMO-- [Comparação de dois métodos de coleta de lágrima para quantificação proteica pelo método de Bradford.] Compararam-se dois métodos de coleta de lágrima para quantificação proteica, utilizando-se 58 olhos de 29 cães hígidos. As amostras foram coletadas utilizando-se fitas de teste da lágrima de Schirmer (Schirmer tear test - STT) e tubos microcapilares. Após obtidas, as amostras foram congeladas a $-80^{\circ} \mathrm{C}$ e posteriormente analisadas pelo método de Bradford. Os resultados foram analisados pelo teste T de Student. A média da concentração proteica e desvio padrão das amostras obtidas com microcapilar foi de $4,45 \mathrm{mg} / \mathrm{mL} \pm 0,35$ e $4,52 \mathrm{mg} / \mathrm{mL} \pm 0,29$ para olhos direito e

\footnotetext{
${ }^{1}$ Received on September 4, 2012.

Accepted for publication on January 23, 2013.

${ }^{2}$ Faculdade de Agronomia e Medicina Veterinária (FAV), Universidade de Brasília (UnB), Campus Dracy Ribeiro, Asa Norte, ICC Sul, Brasília, DF 70910-970, Brazil. *Corresponding author: paulaeye@unb.br

${ }^{3}$ Laboratório de Bioquímica e Químiac de Proteínas, Departamento de Biologia Celular, Instituto de Biologia (IB), Universidade de Brasília, Campus Darcy Ribeiro, Asa Norte, Brasília, DF 70910-970, Brazil
}

esquerdo, respectivamente. Para as amostras obtidas com STT os resultados foram $4,45 \mathrm{mg} / \mathrm{mL} \pm 0,35$ and $4,52 \mathrm{mg} /$ $\mathrm{mL} \pm 0,29$ para olhos direito e esquerdo, respectivamente. Diferenças estatisticamente significativas $(\mathrm{p}<0,001)$ foram encontradas entre os dois métodos. Nas condições em que o trabalho foi conduzido, a média da concentração proteica pelo método de Bradford das amostras obtidas através das tiras do STT foi superior à obtida com o tubo microcapilar. Os valores padrão da concentração protéica da lágrima obtida pelo método de Bradford devem ser analisados considerando-se o método de coleta da lágrima, uma vez que este interfere significativamente nos resultados obtidos.

TERMOS DE INDEXAÇÃO: Lágrima, proteína, Schirmer, microcapillar, Bradford.

\section{INTRODUCTION}

The maintenance of an intact ocular surface depends on the preocular tear film (Gum et al. 2007), a mixture of secretions from main lacrimal and accessory glands, meibomian glands and the corneal and conjunctival epithelium (Petz- 
nick et al. 2011). Its functions are lubrificate and removing the foreign material from the cornea and conjunctiva, providing nutrients to the avascular cornea, and the control of local bacterial flora in some species (Gum et al. 2007).

The relatively low number of proteins identified in previous studies may be due to the limited sensitivity of the methods employed, since using more sensitive methods as a mass spectrometry-based proteomic approach, 491 proteins were identified in the tear fluid (De Souza et al. 2006).

Proteomic analysis has become an important factor to biomedical research, since it is a valuable means of studying the healthy and diseased eye (Markoulli et al. 2001, Petznick et al. 2011), and correlates with systemic or ocular disease (De Souza et al. 2006, Li et al. 2010). The main focus in clinical proteomics is the discovery of new proteins or peptides that work as biomarkers correlated to a specific disease (Couture et al. 2006, Grus et al. 2007, Campos et al. 2008). Metalloproteinases were identified in the dog (Couture et al. 2006) and equine tears from corneal injury (Ollivier et al. 2004), and dogs with cancer showed a different expression pattern of proteins (Campos et al. 2008). Quantitative determination of tear proteins is of increasing interest in ophthalmology, but remains a technical challenge due to the small sample volumes available and the complexity of its composition (Li et al. 2010).

However, variations resulting from different methodologies have been reported (Gachon et al. 1982, Chu et al. 2009). Different protein expression reported may be a result of true biological feature or from methodological variation (Lu et al. 2010). Lowry (Li et al. 2010) and Bradford (Sitaramamma et al. 1998, Ananthi et al. 2008, Li et al. $2010)$ methods were used to quantify proteins from tear samples (Ananthi et al. 2008, Lu et al. 2010). For proteomic analysis, tear samples can be obtained from microcapillary tubes (Gachon et al. 1982, Jones et al. 1997, Couture et al. 2006, Grus et al. 2007, Green-Church et al. 2008) or from Schirmer tear test strips (Grus et al. 2007, Li et al. 2008, Roberts \& Erickson 2008).

As variations in results between methods of protein quantification and of sample collection have been demonstrated (Barabino et al. 2004, Li et al. 2008, Chu et al. 2009), we aim to study comparison of protein concentration from the same animal by the Bradford Method, using two different forms of tear collection, microcapillary tube and STT strip collection.

\section{MATERIALS AND METHODS}

This study was conducted in accordance with the ARVO Statement for the Use of Animals in Ophthalmic and Vision Research and approved by Ethic Committee for Animal Use (process number 7872871/2010).

\section{Animals}

Twenty-nine healthy dogs from different breeds were used. Owners agreed having their dogs included in the research and signed the term of agreement. All dogs underwent complete clinical

\footnotetext{
${ }^{4}$ Kowa SL® - Kowa, Tokyo, Japan.

${ }^{5}$ Schirmer tear test®, Ophthalmos, São Paulo, SP, Brazil.

${ }^{6}$ Tonopen - XL®, Reichert Inc., Depew, NY, USA.
}

and ophthalmic examination, including slit lamp biomicroscopy ${ }^{4}$, Schirmer tear test (STT) ${ }^{5}$, applanation tonometry ${ }^{6}$ and fluorescein stain $^{7}$ before their inclusion in this study. Blood was collected for complete blood count and biochemistry. Dogs with STT below $15 \mathrm{~mm}$ wetting/min were not included in this research.

\section{Tear sample}

Schirmer tear test (STT). Basal tears samples were collected using the $\mathrm{STT}^{2}$. No artificial tear secretion stimulation was performed. The strip was put in the inferior conjunctival fornix, in both eyes, waiting the strip to wet until reaching $30 \mathrm{~mm}$, irrespective elapsed time, using $25 \mu \mathrm{L}$ as the final volume. Each STT was stored in a polypropylene tube ${ }^{5}$ for further processing.

Microcapillary tube. Basal tears samples were also collected 15 minutes after the STT ${ }^{5}$. Tears were collected from manually-restrained dogs using $25 \mu \mathrm{L}$ borosilicate glass microcapillary tubes $^{8}$ placed in the nasal cantus from conjunctival sac, in both eyes, waiting for the complete filling of the tube. Tears were collected always by the same operator and without topical anesthesia.

All samples were transferred immediately to polypropylene tubes ${ }^{8}$ and stored at minus $80^{\circ} \mathrm{C}$ until further processing. After tears collection, eyes were stained with fluorescein ${ }^{7}$ to ensure their integrity.

\section{Tears protein analysis}

Protein extraction from STT ${ }^{5}$ strips was performed by elution with tri-distilled water. Each strip was cut into $3-5 \mathrm{~mm}$ pieces and replaced in the same polypropylene tubes. $500 \mu \mathrm{L}$ MiliQ water was added to this tube which was centrifuged for 30 minutes at $10,000 \mathrm{xg}$. The supernatant was transferred to another polypropylene tube ${ }^{8}$ and stored at $-20^{\circ} \mathrm{C}$ until the next day, when the samples were thawed and centrifuged for 5 minutes at 14,000xg. Samples from microcapillary tubes ${ }^{9}$ proceeded directly to protein quantification without further handling.

Samples collected by both methods were processed by the Bradford method (Bradford 1976). Briefly, $10 \mu \mathrm{L}$ samples from STT and microcappilary ${ }^{9}$ collection methods were mixed to $30 \mu \mathrm{L}$ MiliQ water, $10 \mu \mathrm{L} \mathrm{HCl}^{10} 0,1 \mathrm{M}$ and $300 \mu \mathrm{L}$ Bradford staining solution $^{11}$. The absorbance was measured in a BioRad 3550-UV Microplate Reader at $595 \mathrm{~nm}$. Bovine albumin serum (BAS $)^{12}$ was processed by the same method and used as a standard (Fig.1). Absorbance values from analyzed samples were interpolated in the standard curve (Fig.2) equation to obtain the tears protein concentration. All samples and standards were processed in triplicates. Statistical analysis was done by T-student test with MyNOVA program.

\section{RESULTS}

Using $10 \mu \mathrm{L}$ from STT tears (calculated to the original tear volume), the average protein concentration was $54.5 \mathrm{mg} /$ $\mathrm{mL} \pm 0.63$ and $54.15 \mathrm{mg} / \mathrm{mL} \pm 0$, for right and left eyes, respectively. Average protein concentration from $10 \mu \mathrm{L} \mathrm{mi-}$ crocapillary tears was $4,45 \mathrm{mg} / \mathrm{mL} \pm 0.35$ and $4.52 \mathrm{mg} / \mathrm{mL}$ \pm 0.29 for right and left eyes, respectively. Statistic significant difference $(\mathrm{p}<0.001)$ was found between the methods.

\footnotetext{
${ }^{7}$ Fluorescein strips, Ophthalmos, São Paulo, SP, Brazil.

${ }^{8}$ Polipropilene micro tubes, Axygen Scientific Inc., CA, USA.

${ }^{9}$ Microcaps $囚$, Drummond Scientific Company, Pennsylvania, USA.

${ }^{10} \mathrm{HCl}$ - Hydrochloric acid, Quimex, Brazil.

${ }^{11}$ Bradford solution- Coomassie brilhant blue G250 BioRad and phosphoric acid, VETEC, Brazil.

${ }^{12}$ Bovine albumin serum (BAS)- Bovine Albumin, Sigma-Aldrich, USA.
} 


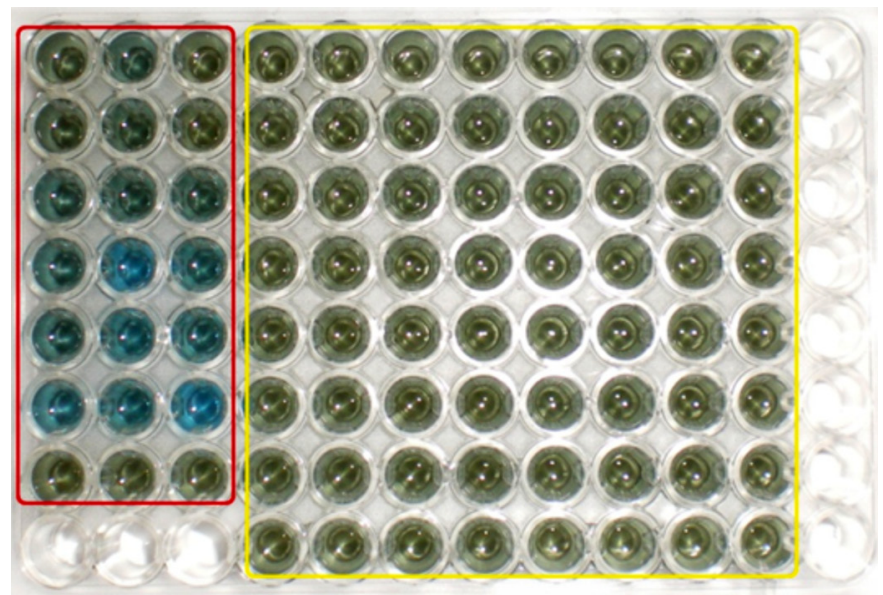

Fig.1. Plaque for spectrophotometry reading. In the red, wells with dilutions for the standard curve, yellow wells with dilutions of the samples from SST strip.

\section{Standard curve}

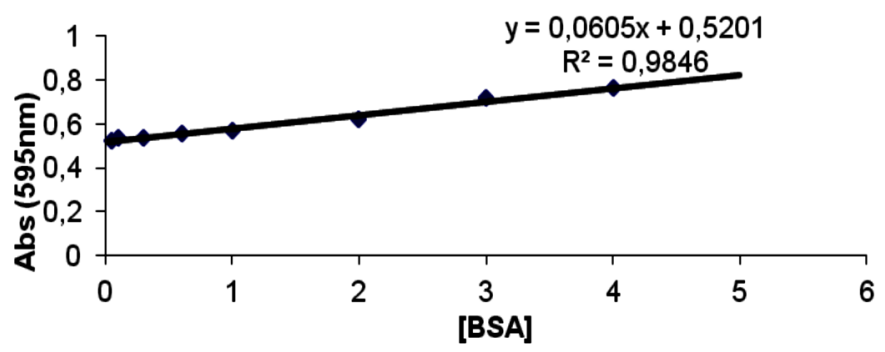

Fig.2. Dispersion of the standard curve and its equation. (Abs = absorbance; $\mathrm{BSA}=$ bovine serum albumin)

No significant difference was found between left and right eyes (standard curve and its equation) $\left(R^{2}=0.9846\right.$ was $y=0.0605 x+0.5201)$ (Fig.2).

\section{DISCUSSION}

Researches with tear proteins have always been performed in humans and animals (Ollivier et al. 2004, Couture et al. 2006), since they provide important information about the course and classification of some diseases and help to find diagnostic and therapeutic targets (Ananthi et al. 2008). The Bradford method is suggested as a sensitive method of tear protein quantification (Sitaramamma et al. 1998, Ham et al. 2007, Ananthi et al. 2008), as we observed. Previous comparisons between the Lowry and Bradford methods for the quantification of tear proteins showed significant differences between both and higher values attributed by the Bradford method, alerting to the need of a careful interpretation of the results (Lu et al. 2010).

Studies reported several techniques used for proteomic analysis of tears, like sodium dodecyl sulfate polyacrylamide gel electrophoresis (SDS-PAGE) (Green-Churchet et al. 2008), enzyme-linked immunosorbent assay (ELISA), high-performance liquid chromatography (HPLC), matrix assisted laser desorption ionization-time of flight (MALDI-TOF) (De Souza et al. 2008), surface-enhanced laser desorption ionization-TOF (SELDI-TOF), liquid chromatography coupled with electrospray ionization (LC/MS) (Zhou et al.
2003) and LTQ-Orbitrap mass spectrometer (De Souza et al. 2008). However, a simple change in the method of obtaining the sample can affect the results (Li et al. 2008), since the quality of the analysis depends on the sample preparation (Ananthi et al. 2008).

Tear samples can be obtained by microcappilary tubes (Ananthi et al. 2008, Yoon et al. 2010, Petznick et al. 2011) or STT (Li et al. 2008), which have been used to collect tear samples and subjected to centrifugation to remove cells and debris (Van Haeringen et al. 1981, Ananthi et al. 2008, Li et al. 2008). Polyester rods were also used for collection and analysis of tears, proving be a viable alternative (Jones et al. 1997). Petznick et al. (2011) analyzed eye-flush tears method in cats and suggested to collect pooling eye-flush tears for tear analysis that need high total protein content. Nevertheless, the method of collection can be challenging, especially in individuals with dry eye (Ham et al. 2007), which encourages the use of STT strip by some researchers (Li et al. 2008).

Microcapillary and STT were previously compared in human tears protein quantification by Bradford method (Green-Church et al. 2008) with some differences from the technique used in this study. In that study, since they did not had a similar volume to compare, the authors used a pool of tears. Also, samples stayed at $4^{\circ} \mathrm{C}$ until analysis.

We have minimized these variations using the same dog with the same tears' volume in each method. In our study the samples were frozen at $-80^{\circ} \mathrm{C}$ (Zhou et al. 2003, Petznick et al. 2011), and stored for no longer than 2 months. It was proved that samples stored at $-70^{\circ} \mathrm{C}$ (Sitaramamma et al. 1998, Ham et al. 2007, Yoon et al. 2010) for up to 4 months preserved the tear proteins better than in $4^{\circ} \mathrm{C}$ or $-20^{\circ} \mathrm{C}$ in a shorter time, when it was observed a reduction in the proteins of the sample (Sitaramamma et al. 1998).

We observed that protein average values from tears in dogs collected with microcapillary tube were close to the values previously described $(6.3 \mathrm{mg} / \mathrm{mL} \pm 0.4 \mathrm{mg} / \mathrm{mL})$ by Barrera et al. (1992). However, protein quantification results obtained from STT strip were higher than the ones obtained from the microcapillary samples. Roberts \& Erickson (2008) analyzed dogs' tears collected with STT by electrophoresis and referred that tear fluids rates below $2.5 \mu \mathrm{L} / \mathrm{min}$ should be considered inadequate in this species. Green-Church et al. (2008) found more total protein collected by the Schirmer strip method compared to the capillary collection method under qualitative comparison, as we observed in our quantitative method. Many unknown factors responsible for tear specific matrix effects appear to remain on the strip following protein extraction, what can be an advantage to antibody and cytokines analysis (Li et al. 2008), but not for the quantification of proteins removed from the strip.

Although standard results can be obtained using only capillary tubes, the insistence on using STT for protein analysis is due to the minimal invasiveness of the method, which makes it an interesting option for proteomics studies (Grus et al. 2007, Li et al. 2008). Besides that, the strip retains ocular surface proteins, considered by some authors an advantage to provide an enriched sample to compare normal 
and pathological environment if the analysis of the ocular surface is desirable (Li et al. 2008). However, we cannot determine if these proteins came from ocular surface or from tears (Li et al. 2008), since STT strips can interact with the epithelium of the ocular surface (Van Haeringen et al. 1981, Green-Church et al. 2008). On the other side, samples collected without touching the cornea or conjunctiva, like with the use of microcapillary cannot carry ocular surface proteins (Li et al. 2008).

\section{CONCLUSION}

In the conditions in which this study was conducted, the average protein concentration of dog's tear from sampling obtained by the Schirmer Tear Test strip showed values higher than those obtained with microcapillary tube. It is suggested that the referee values must be compared according to the method used.

Acknowledgements.- To the National Council for Scientific and Technological Development (CNPq) for Scientific Initiation Grant.

\section{REFERENCES}

Ananthi S., Chitra T., Bini R., Prajna N.V., Lalitha P. \& Dharmalingam K. 2008. Comparative analysis of the tear protein profile in mycotic keratitis patients. Molecular Vision 14:500-507.

Barrera R., Jiménez A., López R., Mañé M.C., Rodríguez J.F. \& Molleda J.M. 1992. Evaluation of total protein content in tears of dogs by polyacrylamide gel disk electrophoresis. Am. J. Vet. Res. 53(4):454-456.

Barabino S., Chena W. \& Dana M.R. 2004. Tear film and ocular surface tests in animal models of dry eye: uses and limitations. Exp. Eye Res. 79:613-621.

Bradford M.M. 1976. Rapid and sensitive method for the quantitation of microgram quantities of protein utilizing the principle of protein-dye binding. Analyt. Biochem. 72:248-254.

Campos C.F.C., Cole N., Dyk D.V., Walsh B.J., Diakos P., Almeida D., Torrecilhas A., Laus J.L. \& Willcox M.D. 2008. Proteomic analysis of dog tears for potential cancer markers. Res. Vet. Sci. 85:349-352.

Chu C.Y., Poon C.W., Pong C.F., Pang C.P. \& Wang C.C. 2009. Human normal tear proteome. Graefes Arch. Clin. Exp. Ophthalmol. 247:725-727.

Couture S., Doucet M., Moreau M. \& Carri M. 2006. Topical effect of various agents on gelatinase activity in the tear film of normal dogs. Vet. Ophthalmol. 9(3):157-164.

De Souza G.A., Godoy L.M.F. \& Mann M. 2006. Identification of 491 proteins in the tear fluid proteome reveals a large number of proteases and protease inhibitors. Genome Biology 7(8):72.

Gachon A.M., Richard J. \& Dastugue B. 1982. Human tears: normal protein pattern and individual protein determinations in adults. Curr. Eye Res. 2(5):301-308.
Green-Church K.B., Nichols K.K., Kleinholz N.M., Zhang L. \& Nic J.J. 2008. Investigation of the human tear film proteome using multiple proteomic approaches. Molecular Vision 14:456-470.

Grus F.H., Joachim S.C. \& Pfeiffer N. 2007. Proteomics in ocular fluids: a review. Proteomics Clin. Appl. 1:876-888.

Gum G.G., Gelatt K.N. \& Esson D.W. 2007. Physiology of the eye, p.149182. In: Gelatt K.N. (Ed.), Veterinary Ophthalmology. $4^{\text {th }}$ ed. Blackwell Publishing, Iowa.

Ham B.M., Jacob J.T. \& Cole R.B. 2007. Single eye analysis and contralateral eye comparison of tear proteins in normal and dry eye model rabbits by MALDI-ToF mass spectrometry using wax-coated target plates. Anal. Bioanal. Chem. 387:889-900.

Jones D.T., Monroy D. \& Pflugfelder S. 1997. A novel method of tear collection: comparison of glass capillary micropippetes with porous polyester rods. Cornea 16(4):450-458.

Markoulli M., Papas E., Petznick A. \& Holden B. 2011. Validation of the Flush Method as an alternative to basal or reflex tear collection. Curr. Eye Res. 36(3):198-207.

Li S., Sack R., Vijmasi, T., Sathe S., Beaton A., Quigley D., Gallup M. \& McNamara N.A. 2008. Antibody protein array analysis of the tear film cytokines. Optometry and Vision Science 85(8):653-660.

Li K., Chen Z., Duan F., Liang J. \& Wu K. 2010. Quantification of tear proteins by SDS-PAGE with an internal standard protein: A new method with special reference to small volume tears. Graefes Arch. Clin. Exp. Ophthalmol. 248:853-862.

Lu T.S., Yiao S.Y., Lim K., Jensen R.V. \& Hsiao L.L. 2010. Interpretation of biological and mechanical variations between the Lowry versus Bradford method for protein quantification. North Am. J. Med. Sci. 2: 325-328.

Olliver F.J., Brooks D.E., Setten G.B.V., Schultz G.S., Gelatt K.N., Stevens G.R., Blalock T.D., Andrew S.E., Komaromy A.M., Lassaline M.E., Kallberg M.E. \& Cutler T.J. 2004. Profiles of matrix etalloproteinase activity in equine tear fluid during corneal healing in 10 horses with ulcerative keratitis. Vet. Ophtalmol. 7(6):397-405.

Petznick A., Evans M.D.M., Madigan M.C., Markoulli M., Garrett Q. \& Sweeney D.F. 2011. A comparison of basaland eye-flush tears for the analysis of cat tear proteins. Acta Ophthalmologica 89:75-81.

Roberts S.R. \& Erickson O.F. 1968. Dog tear secretion and tear proteins. J. Small Anim. Pract. 3(1):1-5.

Sitaramamma T., Shivaji S. \& Rao G.N. 1998. Effect of storage on protein concentration of tear samples. Curr. Eye Res. 17(10):1027-1035.

Van Haeringen N.J. 1981. Clinical biochemistry of tears. Survey Ophthalmol. 26(2):84-96.

Yoon J.S., Choi S.H., Lee J.H., Lee S.J. \& Lee S.Y. 2010. Ocular surface inflammation and nerve growth factor level in tears in active thyroid-associated ophthalmopathy. Graefes Arch. Clin. Exp. Ophthalmol. 248: 271-276.

Zhou L., Beuerman R.W., Barathi A. \& Tan D. 2003. Analysis of rabbit tear proteins by high-pressure liquid chromatography/ electrospray ionization mass spectrometry. Rapid Commun. Mass Spectrom 17:401-412. 